\title{
Penerapan Metode Resampling dalam Mengatasi Imbalanced Data Pada Determinan Kasus Diare Pada Balita di Indonesia
}

Andriansyah Muqiit WS

Politeknik Statistika STIS, 211709554@stis.ac.id

Intan Putri Ananda

Politeknik Statistika STIS

M. Alfa Rizki

Politeknik Statistika STIS

Zahrotin Dwi Hapsari

Politeknik Statistika STIS

Rani Nooraeni

PoliteknikStatistika STIS, raninoor@stis.ac.id

ABSTRAK, Data yang memiliki rasio yang tidak berimbang antara data satu dengan data lainnya dapat dikatakan sebagai imbalanced. Metode Synthetic Minority Oversampling Technique (SMOTE) merupakan metode yang populer diterapkan dalam rangka menangani imbalanced. Pada penelitian ini penulis ingin membandingkan model data sebelum dan data sesudah dilakukan oversampling menggunakan analisis regresi logistik berganda. Data yang digunakan adalah data sekunder dari hasil Survei Demografi dan Kesehatan (SDKI) tahun 2017. Variabel respon (dependent) yang digunakan adalah balita mengalami diare dalam dua minggu terakhir sebelum pencacahan. Variabel penjelas dikelompokkan menjadi dua yaitu faktor sosio-demografi dan faktor lingkungan. Variabel penjelas yang termasuk ke dalam faktor sosio-demografi antara lain jenis kelamin balita, umur balita, umur ibu, dan tingkat pendidikan ibu. Sedangkan variabel penjelas yang merupakan faktor lingkungan antara lain sumber air minum, jenis fasilitas toilet, jenis lantai rumah utama, dan daerah tempat tinggal. Berdasarkan penelitian yang telah dilakukan bahwa penerapan metode SMOTE sangat tepat digunakan untuk meningkatkan keakurasian analisis regresi logistik berganda serta dapat menghindari terjadinya overfitting pada data diare balita di Indonesia tahun 2017 yang memiliki karakteristik imbalanced (rasio tidak berimbang).

Kata Kunci: Imbalanced, Oversampling, SMOTE, Diare

\section{PENDAHULUAN}

Data yang memiliki rasio yang tidak berimbang antara data satu dengan data lainnya dapat dikatakan sebagai imbalanced. Data mining mengartikan imbalanced dengan jumlah data kelas mayoritas lebih banyak dibandingkan dengan kelas minoritas[1]. Penurunan akurasi pada imbalanced disebabkan banyak ditemukan noise atau outlier pada dataset uji yang berasal dari kelas minoritas[2]. Imbalanced pada data yang digunakan akan menghasilkan model yang tidak cocok. Model yang tidak cocok sehubungan dengan terjadinya overfitting dan tidak dapat mengklasifikasikan data dengan baik. Overfitting dapat terjadi dikarenakan kurva logistik yang cenderung mengarah pada salah satu kategori. Hal ini juga disebabkan oleh ketidakseimbangan data yang digunakan dalam pemodelan.

Klasifikasi pada data dengan kelas tidak seimbang (imbalanced) merupakan masalah utama pada bidang machine learning dan data mining, misalnya pada masalah kesehatan. Jika bekerja pada data imbalanced, hampir semua algoritma klasifikasi akan menghasilkan akurasi yang jauh lebih tinggi untuk kelas mayoritas daripada kelas minoritas. Namun pada beberapa kasus, kelas minoritas justru lebih penting untuk diidentifikasi daripada kelas mayoritas[3]. Misalnya kasus diare pada balita, kebanyakan kejadian yang terjadi adalah balita tidak mengalami diare dalam dua minggu sebelum pencacahan, hanya sedikit kasus yang dapat ditemukan dimana balita mengalami kejadian diare.

Logistic Regression merupakan
klasifikasi linier yang telah terbukti
menghasilkan klasifikasi yang powerful dengan
statistik probabilitas dan menangani masalah
klasifikasi multiclass[4]. Metode tersebut cocok
digunakan karena respon yang diamati berskala


kategorik. Namun, Logistic Regression masih memiliki kelemahan yaitu rentan terhadap underfitting/overfitting dan memiliki akurasi yang cenderung rendah[5]. Salah satu hal yang perlu diperhatikan dalam evaluasi model adalah tingkat akurasi sebuah model dalam memprediksi respon dengan benar [6]. Pemodelan dengan Logistic Regression menghasilkan model yang tepat dan tingkat akurasi yang lebih baik apabila imbalanced telah diatasi.

Imbalanced dapat diselesaikan dengan metode resampling, yang merupakan cara paling populer untuk mengatasi masalah imbalanced. Resampling sebagai sarana mengubah distribusi kelas minoritas sehingga tidak kurang terwakili ketika training data pada algoritma machine learning. Metode resampling terbagi menjadi dua yaitu metode oversampling dan undersampling. Metode oversampling adalah metode yang paling sederhana untuk menangani kelas minoritas dengan melakukan random kelas selama proses pengambilan sampel. Proses pengambilan sampel dengan teknik oversampling ini adalah dengan menduplikasi kelas positif dan dilakukan penyeimbangkan kelas secara acak[7]. Namun, karena metode ini menduplikasi kelas positif yang ada dikelas minoritas, kemungkinan terjadi overfitting pasti akan terjadi.

Adapun metode undersampling, metode ini hampir sama dengan metode oversampling yaitu dengan menghitung selisih kelas mayoritas dan kelas minoritas. Selanjutnya dilakukan perulangan sebanyak selisih kelas mayoritas dengan kelas minoritas. Selama proses perulangan dilakukan penghapusan terhadap kelas mayoritas sehingga didapatkan jumlah yang sama dengan kelas minoritas. Metode Synthetic Minority Oversampling Technique (SMOTE) merupakan metode yang populer diterapkan dalam rangka menangani imbalanced. Metode SMOTE ini merupakan pengembangan dari metode oversampling, dimana teknik ini mensintesis sampel baru dari kelas minoritas untuk menyeimbangkan dataset dengan cara sampling ulang sampel kelas minoritas[3].

Kasus kesehatan yang dibahas pada penelitian ini yaitu tentang kasus diare pada balita di Indonesia tahun 2017 (SDKI 2017).
World Health Organization (WHO) tahun 2017 mendefiniskan diare adalah kondisi di mana individu mengalami buang air besar dengan frekuensi sebanyak tiga kali atau lebih dengan konsistensi tinja cair, dapat disertai dengan darah dan atau lendir[8]. Biasanya merupakan gejala infeksi pada saluran usus yang dapat disebabkan oleh berbagai organisme bakteri, virus, dan parasit yang menyebar melalui makanan atau air minum yang terkontaminasi atau dari orang ke orang sebagai akibat dari kebersihan yang buruk.

Diare merupakan penyakit endemis di Indonesia dan juga merupakan penyakit potensial Kejadian Luar Biasa (KLB) yang sering disertai dengan kematian. Diare membawa kematian lebih cepat pada anak-anak dibanding orang dewasa karena terjadinya dehidrasi dan malnutrisi. Angka kematian (CFR) di Indonesia saat KLB Diare masih berada diatas 1 persen kecuali pada tahun 2011 sebesar 0,40 persen. Sedangkan tahun 2018 CFR Diare saat KLB mengalami peningkatan di banding tahun 2017 yaitu menjadi 4,76 persen.

Dari data kasus diare pada balita di SDKI 2017, dimana dari sampel terpilih sebanyak 49.250 rumah tangga, tercatat ada sekitar 11.134 rumah tangga yang memiliki balita, dan hanya ada sekitar 1.560 balita yang mengalami diare dalam dua minggu terakhir pada saat pencacahan. Hal ini menunjukkan bahwa kasus kejadian diare pada balita hanya berkisar 14 persen. Sedangkan sisanya 86 persen balita tidak mengalami diare. Kejadian diare pada balita di Indonesia tahun 2017 ini menggambarkan keadaan imbalanced, dimana kasus balita diare dalam dua minggu terakhir masuk ke dalam kelas minoritas. Sehingga untuk menemukan model yang cocok, keadaan imbalanced harus diatasi.

Penelitian ini bertujuan untuk mengatasi masalah imbalanced dari data diare pada balita di Indonesia tahun 2017 menggunakan metode oversampling dengan metode SMOTE. Kemudian peneliti akan membandingkan model data sebelum dan data sesudah dilakukan oversampling menggunakan analisis regresi logistik berganda untuk melihat model mana yang cocok digunakan dalam mendeterminasikan kasus diare balita di Indonesia tahun 2017. 


\section{TINJAUAN TEORI}

\section{Analisis Regresi Logistik Berganda}

Teknik analisis inferensia yang digunakan dalam penelitian ini adalah model regresi logistik berganda atau multiple logistic regression dengan variabel tak bebas biner di mana variabel bebasnya kontinu dan kategorik. Regresi logistik berganda (multiple logistic regression) adalah suatu analisis regresi yang digunakan untuk menggambarkan hubungan antara variabel bebas dengan sekumpulan variabel terikat, dimana variabel terikat bersifat nominal lebih dari 2 kategorik[9].

Bentuk umum model peluang regersi logistik berganda (multiple logistic regression) dengan $\mathrm{p}$ variabel penjelas (independent), diformulasikan sebagai berikut:

$\pi(x)=\frac{\exp \left(\beta_{0}+\beta_{1} x_{i 1}+\beta_{2} x_{i 2}+\cdots+\beta_{p} x_{i p}\right)}{1+\exp \left(\beta_{0}+\beta_{1} x_{i 1}+\beta_{2} x_{i 2}+\cdots+\beta_{p} x_{i p}\right)}$

Nilai $\pi(\mathrm{x})$ adalah peluang kejadian sukses dengan nilai probabilita $0 \leq \pi(\mathrm{x}) \leq 1$ dan $\beta_{\mathrm{k}}$ adalah nilai parameter dengan $\mathrm{k}=1,2, \ldots, \mathrm{p} . \pi(\mathrm{x})$ merupakan fungsi yang non linier, sehingga perlu dilakukan transformasi ke bentuk logit untuk memperoleh fungsi yang linier agar dapat dilihat hubungan antara variabel respon (dependent) dan variabel penjelas (independent). Dengan melakukan transformasi dari logit $\pi(\mathrm{x})$, maka didapat persamaan:

$$
\begin{aligned}
& g(x)=\ln \frac{\pi(x)}{1-\pi(x)}=\beta_{0}+\beta_{1} x_{i 1}+\beta_{2} x_{i 2}+\cdots+ \\
& \beta_{p} x_{i p}
\end{aligned}
$$

Jika dari beberapa variabel penjelas (dependent) ada yang berskala nominal atau ordinal maka diperlukan variabel dummy. Untuk variabel penjelas (dependent) dengan skala ordinal atau nominal dengan $\mathrm{k}$ kategori diperlukan k-1 variabel dummy.

\section{Metode Synthetic Minority Oversampling Technique (SMOTE)}

Synthetic Minority Oversampling Technique (SMOTE) pertama kali diperkenalkan oleh Nithes V. Chawla sebagai salah satu solusi dalam menangani data tidak seimbang dengan prinsip yang berbeda dengan metode oversampling yang telah diusulkan sebelumnya[10]. Bila Metode oversampling berprinsip memperbanyak pengamatan secara acak, Metode SMOTE menambah jumlah data kelas minor agar setara dengan kelas mayor dengan cara membangkitkan data buatan. Data buatan atau sintesis tersebut dibuat berdasarkan k-tetangga terdekat ( $k$ nearest neighbor). Jumlah k-tetangga terdekat ditentukan dengan mempertimbangkan kemudahan dalam melaksanakannya[6].

Metode ini bekerja dengan mengelompokkan data terdekat yang dipilih berdasarkan jarak Euclidean antara kedua data. Penentuan jumlah replikasi yang dilakukan disesuaikan dengan jumlah anggota pada kelas mayor. Jumlah replikasi harus sesuai dengan jumlah $\mathrm{k}$ pada nearest neighbour, jika jumlah replikasi sebanyak $\mathrm{n}$ maka jumlah $\mathrm{k}$ harus sebanyak n-1.

Misalkan terdapat dua struktur data dengan p dimensi yaitu $x^{t}=\left[x_{1}, x_{2}, \ldots x_{p}\right]$ dan $y^{t}=$ $\left[y_{1}, y_{2}, \ldots y_{p}\right]$, maka jarak Euclidean $\mathrm{d}(\mathrm{x}, \mathrm{y})$ yang dihasilkan antara kedua data ditunjukkan pada persamaan sebagai berikut :

$d(x, y)=$
$\sqrt{\left(x_{1}-y_{1}\right)^{2}+\left(x_{2}-y_{2}\right)^{2}+\cdots+\left(x_{p}-y_{p}\right)^{2}}$

"Synthetic" atau replikasi data dilakukan dengan menggunakan persamaan sebagai berikut:

$x_{\text {syn }}=x_{i}+\left(x_{k n n}-x_{i}\right) \times \tau$

$$
\begin{aligned}
& \text { Dengan: } \\
& x_{\text {syn }}=\text { data hasil replikasi } \\
& x_{i} \quad=\text { data yang akan direplikasi } \\
& x_{k n n}=\text { data yang memiliki jarak terdekat dari } \\
& \text { data yang akan direplikasi } \\
& \tau \quad=\text { bilangan random } 0 \text { sampai } 1
\end{aligned}
$$

\section{METODOLOGI}

Data yang digunakan adalah data sekunder dari hasil Survei Demografi dan Kesehatan (SDKI) tahun 2017 yang dilaksanakan oleh BPS yang berkolaborasi dengan Badan Kependudukan dan Keluarga Berencana Nasional (BKKBN) dan Kementerian Kesehatan. Pada penelitian ini ada dua jenis 
variabel yang digunakan, yaitu variabel penjelas (independent) dan variabel respon (dependent). Variabel respon (dependent) yang digunakan adalah balita mengalami diare dalam dua minggu terakhir sebelum pencacahan. Variabel penjelas dikelompokkan menjadi dua yaitu faktor sosiodemografi dan faktor lingkungan. Variabel penjelas yang termasuk ke dalam faktor sosiodemografi antara lain jenis kelamin balita, umur balita, umur ibu, dan tingkat pendidikan ibu. Sedangkan variabel penjelas yang merupakan faktor lingkungan antara lain sumber air minum, jenis fasilitas toilet, jenis lantai rumah utama, dan daerah tempat tinggal.

\section{Definisi Operasional Variabel}

1. Kejadian diare pada balita terhitung dalam dua minggu sebelum pencacahan. Data yang dihasilkan adalah apakah balita mengalami diare pada sekurang-kurangnya dua minggu yang lalu atau tidak.

2. Umur balita adalah umur balita yang dihitung sejak lahir sampai waktu pencacahan yang dinyatakan dalam tahun.

3. Umur ibu adalah umur ibu yang dihitung sejak lahir sampai waktu pencacahan yang dinyatakan dalam tahun.

4. Jenis kelamin balita adalah perbedaan biologis dan fisiologis yang dapat membedakan laki-laki dan perempuan diukur dengan variabel dummy dan digolongkan dalam dua kategori, yakni diberi skor 0 apabila balita berjenis kelamin perempuan dan diberi skor 1 apabila balita berjenis kelamin laki-laki.

5. Daerah tempat tinggal menunjukkan wilayah dimana balita sehari-hari berdomisili, digolongkan dengan variabel dummy dan diberi skor 0 apabila balita berdomisili di pedesaan dan skor 1 apabila balita berdomisili di perkotaan.

6. Tingkat pendidikan tertinggi menunjukkan pendidikan terakhir yang ditamatkan oleh ibu yang digolongkan menjadi 4 kategori, yaitu tidak bersekolah, SD/sederajat, $\mathrm{SMP} /$ sederajat, dan SMA/sederajat.

7. Jenis lantai rumah utama menunjukkan jenis lantai rumah tinggal yang digolongkan menjadi 3 kategori, yaitu lantai alami, lantai bahan, dan lantai jadi.
8. Jenis fasilitas toilet menunjukkan jenis jamban yang digunakan pada rumah tinggal balita yang digolongkan menjadi 4 kategori, yaitu jamban layak, jamban bersama, jamban tidak layak, dan tidak memiliki jamban.

9. Sumber air minum utama menunjukkan kelayakan sumber air minum utama balita yang diukur dengan variabel dummy dan digolongkan dalam 2 kategori, yaitu diberi skor 0 apabila sumber air minum utama tidak layak dan diberi skor 1 apabila sumber air minum utama layak.

\section{PEMBAHASAN}

\section{Gambaran Umum Oversampling}

Perbandingan antara balita yang mengalami diare dua minggu yang lalu dan yang tidak, berdasarkan SDKI 2017 memiliki perbedaan yang cukup besar yakni dari 11.134 balita hanya 1.560 saja yang mengalami diare. Dapat dilihat dari gambar 1 bahwa persentase balita yang mengalami diare dua minggu terakhir dengan yang tidak mengalami sangat berbeda. Persentase balita yang mengalami diare dua minggu terakhir sebesar 14 persen sedangkan yang tidak mengalami diare sebesar 86 persen.

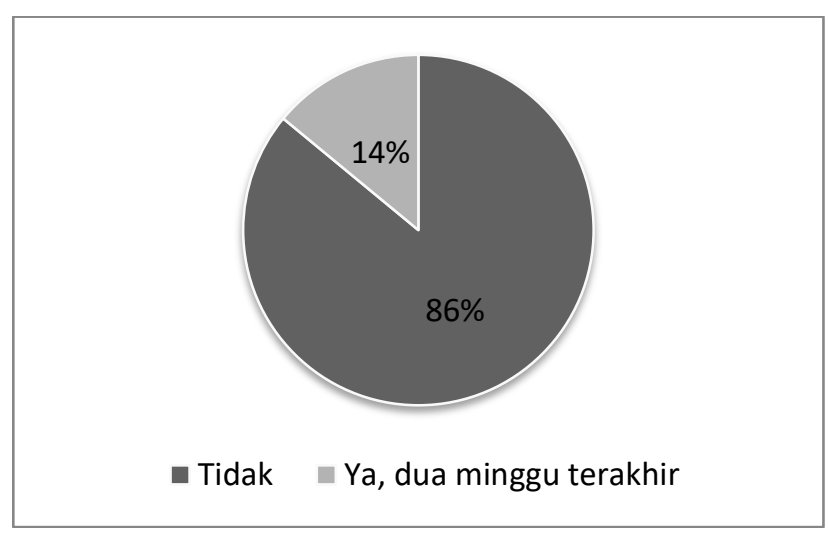

Gambar 1. Persentase kejadian diare pada balita di Indonesia tahun 2017

Data seperti ini apabila dilakukan pemodelan akan berakibat fatal dan hasil estimasinya tidak representatif. Oleh karena itu, dengan dilakukannya oversampling dengan metode SMOTE data akan lebih proporsional. 
Tabel 1. Perbandingan Jumlah Kejadian Diare Balita Pada Data Sebelum dan Sesudah Oversampling.

\begin{tabular}{lcc} 
Kejadian & \multicolumn{2}{c}{ Data } \\
\cline { 2 - 3 } Diare Balita & Sebelum & $\begin{array}{c}\text { Hasil } \\
\text { Oversampling }\end{array}$ \\
\hline $\begin{array}{c}\text { Ya, 2 minggu } \\
\text { yang lalu }\end{array}$ & 1560 & 4680 \\
\hline Tidak & 9574 & 6240 \\
Jumlah & 11134 & 10920 \\
\hline
\end{tabular}

Sumber: SDKI 2017 (data diolah)

Dari Tabel 1 terlihat data sebelum dan sesudah dilakukan oversampling perbedaannya sangat jauh. Data sebelum dilakukan oversampling tidak proporsional, dimana balita yang tidak mengalami diare jumlah kejadiannya lebih banyak daripada yang mengalami diare. Tetapi setelah dilakukan oversampling perbandingan data kejadian diare pada balita menjadi lebih proporsional.

\section{Pemodelan Data Dengan Regresi Logistik Berganda}

Pemodelan dilakukan menggunakan analisis regresi logistik berganda dengan data sebelum dan sesudah dilakukan oversampling. Sehingga diperoleh hasil pengujian secara simultan dengan menggunakan statistic uji $G$ sebagai berikut.
Tabel 2. Omnibus Test of Model Coefficients

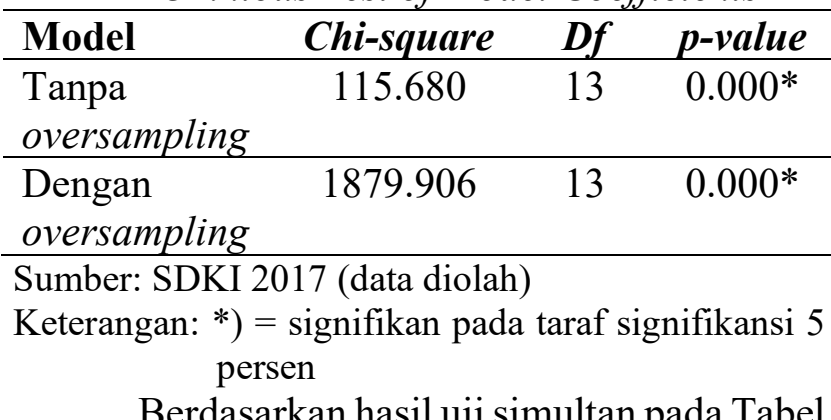

Berdasarkan hasil uji simultan pada Tabel 2 diperoleh hasil p-value untuk model tanpa oversampling sebesar 0.000 . Dikarenakan $p$ value tersebut nilainya lebih kecil dari 5 persen, maka dengan tingkat signifikansi 5 persen dapat disimpulkan bahwa terdapat cukup bukti untuk menyatakan bahwa minimal terdapat satu variabel bebas yang berpengaruh signifikan secara statistik terhadap kejadian diare pada balita di Indonesia tahun 2017.

Pada model dengan oversampling diperoleh hasil p-value sebesar 0.000 . Dikarenakan $p$-value tersebut nilainya lebih kecil dari 5 persen, maka dengan tingkat signifikansi 5 persen dapat disimpulkan bahwa terdapat cukup bukti untuk menyatakan bahwa minimal terdapat satu variabel bebas yang berpengaruh signifikan secara statistik terhadap kejadian diare pada balita di Indonesia tahun 2017 pada data oversampling. Selanjutnya adalah melakukan estimasi dengan regresi logistik berganda. Diperoleh hasil estimasi pada Tabel 3 sebagai berikut.

Tabel 3. Estimasi Parameter Tanpa dan Dengan Oversampling (SPSS)

\begin{tabular}{lclcc}
\hline \multirow{2}{*}{ Nama Variabel } & Variabel & Kategori & \multicolumn{2}{c}{ Estimasi $\beta$} \\
\cline { 3 - 5 } & $\mathrm{X}_{1}$ & & $\begin{array}{c}\text { Tanpa } \\
\text { oversampling }\end{array}$ & $\begin{array}{c}\text { Dengan } \\
\text { oversampling }\end{array}$ \\
\hline Umur balita & $\mathrm{X}_{2}$ & & -0.006 & -0.029 \\
\hline Umur ibu & $\mathrm{D}_{1}$ & $\begin{array}{l}\text { Laki-laki } \\
\text { Perempuan* }\end{array}$ & -0.032 & -0.037 \\
\hline Jenis kelamin balita & $\mathrm{D}_{2}$ & $\begin{array}{l}\text { Perkotaan } \\
\text { Pedesaan* }\end{array}$ & -0.080 \\
\hline $\begin{array}{l}\text { Daerah tempat } \\
\text { tinggal }\end{array}$ & $\mathrm{D}_{31}$ & $\begin{array}{l}\text { Tidak bersekolah } \\
\text { SMA/sederajat* }\end{array}$ & 0.485 & -0.162 \\
\hline $\begin{array}{l}\text { Tingkat pendidikan } \\
\text { tertinggi ibu }\end{array}$ & & SD/sederajat & 0.372 & 0.883 \\
\cline { 2 - 5 } & $\mathrm{D}_{32}$ & & & 0.411
\end{tabular}




\begin{tabular}{|c|c|c|c|c|}
\hline \multirow{4}{*}{ Nama Variabel } & \multirow{3}{*}{ Variabel } & \multirow[b]{2}{*}{ Kategori } & \multicolumn{2}{|c|}{ Estimasi $\beta$} \\
\hline & & & $\begin{array}{c}\text { Tanpa } \\
\text { oversampling }\end{array}$ & $\begin{array}{c}\text { Dengan } \\
\text { oversampling }\end{array}$ \\
\hline & & SMA/sederajat* & & \\
\hline & $\mathrm{D}_{33}$ & $\begin{array}{l}\text { SMP/sederajat } \\
\text { SMA/sederajat* }\end{array}$ & 0.223 & 0.129 \\
\hline \multirow[t]{2}{*}{$\begin{array}{l}\text { Jenis lantai rumah } \\
\text { utama }\end{array}$} & $\mathrm{D}_{41}$ & $\begin{array}{l}\text { Lantai alami } \\
\text { Lantai jadi* }\end{array}$ & -0.318 & 0.331 \\
\hline & $\mathrm{D}_{42}$ & $\begin{array}{l}\text { Lantai bahan } \\
\text { Lantai jadi* }\end{array}$ & 0.077 & 0.881 \\
\hline \multirow[t]{3}{*}{ Jenis fasilitas toilet } & $\mathrm{D}_{51}$ & $\begin{array}{l}\text { Jamban layak } \\
\text { Tidak ada* }\end{array}$ & -0.180 & -0.848 \\
\hline & $\mathrm{D}_{52}$ & $\begin{array}{l}\text { Jamban bersama } \\
\text { Tidak ada* }\end{array}$ & -0.015 & -0.170 \\
\hline & $\mathrm{D}_{53}$ & $\begin{array}{l}\text { Jamban tidak } \\
\text { layak } \\
\text { Tidak ada* }\end{array}$ & -0.338 & -0.810 \\
\hline $\begin{array}{l}\text { Sumber air minum } \\
\text { utama }\end{array}$ & $\mathrm{D}_{6}$ & $\begin{array}{l}\text { Layak } \\
\text { Tidak layak* }\end{array}$ & -0.113 & 1.190 \\
\hline Konstan & & & -0.897 & 1.009 \\
\hline
\end{tabular}

Sumber: SDKI 2017 (data diolah)

Keterangan: $\left.{ }^{*}\right)=$ kategori referensi

Tabel 4. Hasil Uji Parsial Tanpa dan Dengan Oversampling (SPSS)

\begin{tabular}{|c|c|c|c|c|}
\hline \multirow[b]{2}{*}{ Nama Variabel } & \multirow[b]{2}{*}{ Variabel } & \multirow[b]{2}{*}{ Kategori } & \multicolumn{2}{|c|}{ Sig. } \\
\hline & & & $\begin{array}{c}\text { Tanpa } \\
\text { oversampling }\end{array}$ & $\begin{array}{c}\text { Dengan } \\
\text { oversampling }\end{array}$ \\
\hline Umur balita & $\mathrm{X}_{1}$ & & 0.738 & $0.048 * *$ \\
\hline Umur ibu & $\mathrm{X}_{2}$ & & $0.000 * *$ & $0.000 * *$ \\
\hline \multirow{2}{*}{$\begin{array}{l}\text { Jenis kelamin } \\
\text { balita }\end{array}$} & $\mathrm{D}_{1}$ & Laki-laki & $0.014 * *$ & 0.060 \\
\hline & & Perempuan* & & \\
\hline $\begin{array}{l}\text { Daerah tempat } \\
\text { tinggal }\end{array}$ & $\mathrm{D}_{2}$ & $\begin{array}{l}\text { Perkotaan } \\
\text { Pedesaan* }\end{array}$ & $0.039 * *$ & $0.000 * *$ \\
\hline \multirow[t]{3}{*}{$\begin{array}{l}\text { Tingkat pendidikan } \\
\text { tertinggi ibu }\end{array}$} & $D_{31}$ & $\begin{array}{l}\text { Tidak } \\
\text { bersekolah } \\
\text { SMA/sederajat* }\end{array}$ & $0.020 * *$ & $0.000 * *$ \\
\hline & $\mathrm{D}_{32}$ & $\begin{array}{l}\text { SD/sederajat } \\
\text { SMA/sederajat* }\end{array}$ & $0.000 * *$ & $0.000 * *$ \\
\hline & $D_{33}$ & $\begin{array}{l}\text { SMP/sederajat } \\
\text { SMA/sederajat* }\end{array}$ & $0.010 * *$ & 0.053 \\
\hline \multirow[t]{2}{*}{$\begin{array}{l}\text { Jenis lantai rumah } \\
\text { utama }\end{array}$} & $\mathrm{D}_{41}$ & $\begin{array}{l}\text { Lantai alami } \\
\text { Lantai jadi* }\end{array}$ & $0.034 * *$ & $0.000^{* *}$ \\
\hline & $\mathrm{D}_{42}$ & $\begin{array}{l}\text { Lantai bahan } \\
\text { Lantai jadi* }\end{array}$ & 0.324 & $0.000 * *$ \\
\hline Jenis fasilitas toilet & $\mathrm{D}_{51}$ & $\begin{array}{l}\text { Jamban layak } \\
\text { Tidak ada* }\end{array}$ & $0.045 * *$ & $0.000 * *$ \\
\hline
\end{tabular}




\begin{tabular}{|c|c|c|c|c|}
\hline \multirow{4}{*}{ Nama Variabel } & \multirow{3}{*}{$\begin{array}{c}\text { Variabel } \\
D_{52}\end{array}$} & \multirow{3}{*}{$\begin{array}{l}\text { Kategori } \\
\text { Jamban } \\
\text { bersama } \\
\text { Tidak ada* }\end{array}$} & \multicolumn{2}{|c|}{ Sig. } \\
\hline & & & $\begin{array}{c}\text { Tanpa } \\
\text { oversampling }\end{array}$ & $\begin{array}{c}\text { Dengan } \\
\text { oversampling }\end{array}$ \\
\hline & & & 0.892 & $0.030 * *$ \\
\hline & $\mathrm{D}_{53}$ & $\begin{array}{l}\text { Jamban tidak } \\
\text { layak } \\
\text { Tidak ada* }\end{array}$ & $0.036 * *$ & $0.000 * *$ \\
\hline $\begin{array}{l}\text { Sumber air minum } \\
\text { utama }\end{array}$ & $\mathrm{D}_{6}$ & $\begin{array}{l}\text { Layak } \\
\text { Tidak layak* }\end{array}$ & 0.191 & $0.000 * *$ \\
\hline Konstan & & & $0.014 * *$ & $0.000 * *$ \\
\hline
\end{tabular}

Sumber: SDKI 2017 (data diolah)

Keterangan: $\left.{ }^{*}\right)=$ kategori referensi $\left.{ }^{* *}\right)=$ signifikan pada taraf signifikansi 5 persen

Berdasarkan hasil pengujian parsial pada Tabel 4, hasil dari model yang tanpa oversampling diperoleh 9 variabel yang berpengaruh terhadap kejadian diare pada balita di Indonesia yakni dilihat dari $p$-value yang nilainya lebih kecil dari tingkat signifikansi 5 persen. Oleh karena itu, dengan tingkat signifikansi 5 persen dapat disimpulkan bahwa terdapat cukup bukti untuk menyatakan bahwa umur ibu dari balita, jenis kelamin balita, daerah tempat tinggal, tingkat pendidikan tertinggi ibu kategori tidak bersekolah, SD/sederajat, dan $\mathrm{SMP} /$ sederajat, jenis lantai rumah kategori lantai alami, jenis fasilitas toilet kategori jamban layak dan jamban tidak layak.
Sedangkan untuk hasil dari model dengan oversampling diperoleh 11 variabel yang berpengaruh terhadap kejadian diare pada balita di Indonesia yakni dilihat dari p-value yang nilainya lebih kecil dari tingkat signifikansi 5 persen. Oleh karena itu, dengan tingkat signifikansi 5 persen dapat disimpulkan bahwa terdapat cukup bukti untuk menyatakan bahwa umur balita, umur ibu dari balita, daerah tempat tinggal, tingkat pendidikan tertinggi ibu kategori tidak bersekolah dan SD/sederajat, jenis lantai rumah kategori lantai alami dan lantai bahan, jenis fasilitas toilet kategori jamban layak, jamban bersama, dan jamban tidak layak, dan sumber air minum utama.

Tabel 5. Prediksi dan Klasifikasi (tanpa oversampling)

\begin{tabular}{ccccc}
\hline & & \multicolumn{3}{c}{ Prediksi } \\
\cline { 2 - 5 } & Tidak & Tidak & $\begin{array}{c}\text { Ya, 2 minggu } \\
\text { terakhir }\end{array}$ & Persentase \\
\hline \multirow{2}{*}{ Observasi } & 9574 & 0 & 100 \\
\cline { 2 - 5 } & Ya, 2 minggu terakhir & 1560 & 0 & 0 \\
\hline & Persentase & & & 86.0 \\
\hline
\end{tabular}

The cut value is 0.5

Sumber: SDKI 2017 (data diolah).

Tabel 6. Prediksi dan Klasifikasi (oversampling) 


\begin{tabular}{|c|c|c|c|c|}
\hline & \multicolumn{4}{|c|}{ Prediksi } \\
\hline & Tidak & $\begin{array}{c}\text { Ya, } 2 \text { minggu } \\
\text { terakhir }\end{array}$ & & \\
\hline \multirow{2}{*}{ Observasi } & Tidak & 5110 & 1130 & 81.9 \\
\hline & Ya, 2 minggu terakhir & 2231 & 2449 & 52.3 \\
\hline & Persentase & & & 69.2 \\
\hline
\end{tabular}

The cut value is 0.5

Sumber: SDKI 2017 (data diolah)

Berdasarkan Tabel 5, dapat diketahui bahwa model regresi logistik berganda pada data sebelum dilakukan oversampling terjadi overfitting. Salah satu indikasi terjadinya overfitting adalah dari hasil tabel prediksi dan klasifikasinya ternyata model regresi logistik tidak mampu memprediksi kejadian diare pada balita berdasarkan variabel independen yang ada.

Sedangkan pada Tabel 6, dapat diketahui bahwa dengan menggunakan data hasil oversampling, model regresi logistik berganda mampu memprediksi kejadian diare pada balita berdasarkan variabel independen yang ada. Persentase hasil prediksinya adalah sebesar 69.2 persen. Dikarenakan oversampling dapat mengatasi terjadinya overfitting pada data yang tidak berimbang (imbalanced data), maka model regresi logistik berganda dengan oversampling lebih cocok untuk memodelkan kejadian diare pada balita.

\section{Interpretasi Model Terbaik}

Berdasarkan hasil estimasi pada Tabel 3, maka dengan menggunakan persamaan (2) model regresi logistik berganda untuk kejadian diare pada balita adalah sebagai berikut:

$$
\begin{aligned}
\hat{g}(x)= & 1.009-0.029 X_{1}-0.037 X_{2}- \\
& 0.080 D_{1}-0.162 D_{2}+0.883 D_{31}+ \\
& 0.411 D_{32}+0.129 D_{33}+0.331 D_{41}+ \\
& 0.881 D_{42}-0.848 D_{51}-0.170 D_{52}- \\
& 0.810 D_{53}+1.190 D_{6}
\end{aligned}
$$

Dalam menginterpretasikan hasil estimasi model regresi logistik berganda adalah dengan melihat rasio kecenderungan dari masing-masing variabel. Nilai rasio kecenderungan untuk setiap variabel adalah sebesar $\exp (\hat{\beta})$ berdasarkan nilai dari masing-masing koefisien $\hat{\beta}$. Sehingga interpretasinya adalah sebagai berikut:

a. Umur balita

Setiap bertambahnya umur balita sebesar satu tahun, maka kecenderungan seorang balita untuk mengalami diare adalah sebesar $\exp (-0.029)=0.971$ kali lebih kecil.

b. Umur ibu

Setiap bertambahnya umur ibu sebesar satu tahun, maka kecenderungan seorang balita untuk mengalami diare adalah sebesar $\exp (-0.037)=0.964$ kali lebih kecil.

c. Jenis kelamin balita

Balita berjenis kelamin laki-laki memiliki kecenderungan untuk mengalami diare sebesar $\exp (-0.080)=0.923$ kali lebih kecil dibandingkan dengan balita berjenis kelamin perempuan.

d. Daerah tempat tinggal

Balita yang bertempat tinggal di daerah perkotaan memiliki kecenderungan untuk mengalami diare sebesar $\exp (-0.162)=$ 0.85 kali lebih kecil dibandingkan dengan yang bertempat tinggal di daerah perdesaan.

e. Tingkat pendidikan tertinggi ibu

Balita yang ibunya tidak bersekolah, berpendidikan $\mathrm{SD} /$ sederajat, dan berpendidikan SMP/sederajat memiliki kecenderungan untuk mengalami diare masing-masing sebesar 2.418, 1.554, dan 1.138 kali lebih besar dibandingkan dengan yang berpendidikan SMA/sederajat.

f. Jenis lantai rumah utama

Balita yang jenis lantai rumah utamanya berupa lantai alami dan lantai bahan memiliki kecenderungan untuk mengalami diare sebesar 1.392 dan 2.413 kali lebih besar dibandingkan dengan yang lantai jadi. 
g. Jenis fasilitas toilet

Balita yang jenis fasilitas toiletnya layak, bersama, dan tidak layak memiliki kecenderungan untuk mengalami diare masing-masing sebesar 0.428, 0.844, dan 0.445 kali lebih kecil dibandingkan dengan yang tidak memiliki fasilitas.

h. Sumber air minum utama

Balita yang sumber air minum utamanya layak memiliki kecenderungan untuk mengalami diare sebesar 3.288 lebih besar dibandingkan dengan balita yang sumber air minumnya tidak layak. Terjadi misleading pada variabel sumber air minum utama. Seharusnya kecenderungan lebih besar untuk sumber air minum tidak layak, akan tetapi berdasarkan data yang ada ketika dimodelkan memberikan hasil yang sebaliknya. Sehingga dalam hal ini perlu peninjauan ulang terkait kriteria sumber air minum yang layak.

\section{KESIMPULAN}

Berdasarkan penelitian yang telah dilakukan, model analisis regresi logistik berganda dengan pendekatan SMOTE (oversampling) memiliki tingkat akurasi pengklasifikasian yang cukup baik untuk kelas minoritas pada kejadian diare pada balita di Indonesia tahun 2017 dan tidak terjadi overfitting. Selain itu, pada uji parsial (uji Wald) model dengan data oversampling menghasilkan lebih banyak variabel yang signifikan dibandingkan dengan model dengan data tanpa oversampling. Dengan demikian dapat disimpulkan bahwa penerapan metode SMOTE sangat tepat digunakan untuk meningkatkan keakurasian analisis regresi logistik berganda serta dapat menghindari terjadinya overfitting pada data diare balita di Indonesia tahun 2017 yang memiliki karakteristik imbalanced (rasio tidak berimbang).

\section{DAFTAR PUSTAKA}

[1] Untoro, Meida Cahyo dan Joko Lianto Buliali. (2018). Penanganan imbalance class data laboratorium kesehatan dengan Majority Weighted Minority Oversampling
Technique. Jurnal Ilmiah Teknologi Sistem Informasi 4 (1), 2018, 23-29.

[2] Almeida, J., Barbosa, L., Pais, A., \& Formosinho, S. (2007). Improving hierarchical cluster analysis: A new method with outlier detection and automatic clustering. Chemometrics and Intelligent Laboratory Systems, 2007(2007), 208-217

[3] Siringoringo, Rimbun. (2018). Klasifikasi Data Tidak Seimbang Menggunakan Algoritma SMOTE Dan K-Nearest Neighbor. Jurnal ISD Vol.3 No.1 Januari - Juni 2018.

[4] Karsmakers, P., Pelckmans, K., \& Suykens, J. a. K. (2007). Multiclass kernel logistic regression: a fixed-size implementation. 2007 International Joint Conference on Neural Networks.

[5] Harrington, P. (2012). Machine Learning in Action. Manning Publications Co.

[6] Barro, Rossi Azmatul, dkk. (2013). Penerapan Synthetic Minority Oversampling Technique (SMOTE) terhadap Data Tidak Seimbang pada Pembuatan Model Komposisi Jamu. Jurnal Xplore Vol.1, 2013, 1-6.

[7] Ganganwar, Vaishali. (2012). An Overview of Classification Algorithms for Imbalanced Datasets. International Journal of Emerging Technology and Advanced Engineering Vol.2 Issue 4, April 2012, $42-47$.

[8] WHO. 2017. Diarrhoeal Disease. https://www.who.int/en/news-room/factsheets/detail/diarrhoeal-disease. Diakses pada 15 Februari 2020.

[9] Astuti, Anna Puji. 2019. Variabel-variabel yang Mempengaruhi Kejadian Persalinan Lama di Indonesia (Analisis Data SDKI 2017). Jakarta: Politeknik Statistika STIS.

[10] Chawla, Nitesh V., dkk. 2018. SMOTE for Learning from Imbalanced Data: Progress and Challenges, Marking the 15-year Anniversary. Journal of Artificial Intelligence Research 61, 2018, 863-905. 